\title{
Protistan bacterivory and benthic microbial biomass in an intertidal creek mudflat
}

\author{
Matthew R. First* ${ }^{*}$ James T. Hollibaugh \\ Department of Marine Sciences, The University of Georgia, Athens, Georgia 30602-3636, USA
}

\begin{abstract}
We examined 8 sediment samples collected at $3 \mathrm{~h}$ intervals at Dean Creek (Sapelo Island, Georgia) to assess the impact of protist bacterivory on the standing crops of benthic bacterial biomass. The combined biomass of the benthic microalgae (BMA), bacteria, heterotrophic protists, and meiofauna ranged from 0.41 to $0.57 \mathrm{mg} \mathrm{C} \mathrm{g}^{-1}$ wet sediment (gws) in the samples examined. BMA represented $>80 \%$ of total biomass and remained relatively stable throughout the study period. Bacterial biomass ranged from 28 to $91 \mu \mathrm{g} \mathrm{gws}^{-1}$ (5 to $16 \%$ of total biomass) in the samples. Heterotrophic protists (mainly ciliates, flagellates, and testate amoeba) and meiofauna (mainly nematodes) each contributed small $(<1 \%$ each) amounts to the total biomass. Protist grazing accounted for the loss of $<1.1$ and $<4.7 \% \mathrm{~h}^{-1}$ of the total and enzymatically active bacterial standing stock, respectively. Grazing rates were highest in the morning samples, concurrent with the highest portion of potentially active bacteria. However, there was no statistically significant change in grazing impact throughout the day and in most cases bacterivory would not reduce the standing bacterial biomass. Food web simulations demonstrate that the confluence of protist loss factors (such as meiofaunal predation) and reduced grazing at low bacterial concentrations can limit the production of bacterivorous protists and, in turn, their use of the large store of benthic bacterial biomass.
\end{abstract}

KEY WORDS: Tidal creeks - Sapelo Island - Salt marsh · Microzoobenthos · Microphytobenthos · Ciliates $\cdot$ Meiofauna $\cdot$ Benthic food web

Resale or republication not permitted without written consent of the publisher

\section{INTRODUCTION}

Marine sediments harbor both high abundance and high diversity of prokaryotes (Torsvik et al. 1996). Bacterial standing crop is several orders of magnitude greater in sediments than in the water column and (when scaled to porosity) remains relatively constant across a range of environments (Schmidt et al. 1998). This constancy suggests that there are strong controls on benthic bacterial biomass, either bottom-up (supply of growth substrate), top-down (predation), or via selfregulation through quorum sensing (Schmidt et al. 1998). Because of the higher bacterial biomass in sediments, the flux of primary production passed to metazoans through bacteria and bacterivores may be substantial (Kemp 1990). The combined bactivory of benthic ciliates, flagellates, and meiofauna can account for a large portion of bacterial production (Epstein 1997). Yet bacterivory by ciliates (a major component of the marine microbenthos, Fenchel 1967) has been estimated as only a small fraction of benthic bacterial production (Kemp 1988). When measured simultaneously, bacterial production often exceeds grazing loss (Epstein 1997, Hamels et al. 2001). The enigmatic co-occurrence of high production, low protistan grazing rates, and stable bacterial standing stock has also been observed in freshwater sediments (Wieltschnig et al. 2003).

One potential explanation is that other loss mechanisms, such as invertebrate deposit feeders or viral lysis, balance benthic bacterial production. Detritivorous meiofauna rely upon particle-associated bacteria and protists for nutrition (Fenchel 1970). However, the abundance and production of invertebrate deposit feeders is low relative to benthic bacteria, effectively preventing the control of bacterial populations (Kemp 1987). Viral particles are present in high concentrations in the sediment, but the rate of viral lysis is gen- 
erally lower than that observed in the water column (e.g. Glud \& Middelboe 2004), and in some benthic systems viral infection occurs in $<0.1 \%$ of bacterial cells (Filippini et al. 2006).

Salt marsh sediments are subject to periodic tidal inundation. Tidal advection drives the resuspension of benthic microbes into the water column (Shimeta \& Sisson 1999). These benthic microbes are an important component of the pelagic food web (De Jonge \& Van Beusekom 1992). For example, benthic diatoms represent approximately one-third of all diatoms ingested by oysters in the headwaters of tidal rivers (Thoresen 2004). Patterns of suspension and settling of intertidal bacterivores could lead to periods of the day when relatively higher abundances of bacterivorous protists significantly impact the benthic bacterial community.

The goal of the present study was to test the hypothesis that protistan grazing impact on benthic bacteria varies significantly throughout the day. This variation could be due to either (1) change in the abundance of heterotrophic protists relative to bacteria or (2) fluctuations in individual grazing rates throughout the day. To test this, we recorded the biomass of benthic microbes (bacteria, protists, microalgae, meiofauna) in samples from an intertidal mudflat and measured grazing rates of protists on bacteria in each sample 8 times throughout the day. A simple predator-prey model was used to interpret experimental results and to examine the potential role of bacterivory in controlling bacterial biomass and dynamics of protist bacterivores.

\section{MATERIALS AND METHODS}

Sampling. The site selected for sampling was located beneath a foot-bridge crossing Dean Creek on Sapelo Island, Georgia (USA). Sampling was conducted from 28 to 29 July 2005 by lowering a sediment grab sampler onto a $2 \mathrm{~m}^{2}$ mudflat that was uniform in elevation and color and contained no visible crab burrows. Sampling from the bridge allowed quick access to the site without disturbing the surrounding sediments. Sampling started at 06:00 $\mathrm{h}$ and occurred at $3 \mathrm{~h}$ intervals thereafter. Samples are distinguished by the time at which they were collected (e.g. $\mathrm{T}_{0600}, \mathrm{~T}_{0900}$, etc.). A complete description of the sediment sampling protocol will be made available elsewhere (authors' unpubl. data). Three replicate samples $(\sim 40 \mathrm{ml})$ were collected by scraping the top $1 \mathrm{~cm}$ off the sediment from 3 areas roughly $10 \mathrm{~cm}$ apart in the grab sampler. This sediment was placed in plastic containers, mixed with a metal spatula, and subsampled for analysis of photopigments, bacteria, protists, and meiofauna, and for grazing experiments.
Biomass. Biomass is reported per gram of wet sediment (gws). Intertidal sediments can compact during tidal emersions due to dewatering; long periods of emersion ( 2 to $3 \mathrm{~h}$ ) can result in significantly different estimates of biomass density (Perkins et al. 2003). At the location sampled, sediments were emersed from 09:25 to $12: 05 \mathrm{~h}$ on 28 July 2005 and from $23: 40$ to $00: 26 \mathrm{~h}$ on 29 July 2005. Thus, the only sampling occasion at which biomass density was likely to be affected by compaction was at 12:00 h. We analyzed the porosity of fluorescently labeled embedded cores (FLEC) collected from these grab samples to determine if there was a significant difference between the cores collected at 12:00 and 15:00 $\mathrm{h}$ (during tidal submersion). The sediments were composed mostly of large sand grains (grain size $259 \pm 113 \mu \mathrm{m}$, mean $\pm \mathrm{SD}$ ). FLEC profiles were analyzed via laser scanning confocal microscopy (authors' unpubl. data). Sand grains had no fluorescence in contrast to the slight background fluorescence of the epoxy embedding media. Thus, porosity of these 2 different cores was determined by the relative portion of sand grain area to interstitial area.

Benthic microalgae. Three analytical replicate samples (approximately $5 \mathrm{gws}$ ) were placed in $15 \mathrm{ml}$ centrifuge tubes with $0.5 \mathrm{ml}$ of $0.22 \mu \mathrm{m}$ filtered sea water (FSW). The FSW was saturated with $\mathrm{MgCO}_{3}$ to stabilize chlorophyll $a(\mathrm{chl} a)$. The samples were frozen $\left(-20 \pm 2^{\circ} \mathrm{C}\right)$ and kept in the dark prior to and during extraction and analysis. Pigments were extracted from sediment samples for $24 \mathrm{~h}$ with a solution consisting of $45 \%$ acetone, $45 \%$ methanol, and $10 \%$ water. Sample tubes were vortexed at high speed for 1 min every 8 to $10 \mathrm{~h}$ throughout the extraction period. Samples were then centrifuged $(20 \mathrm{~min}$ at $5000 \times g)$, and absorbance spectra (485 to $750 \mathrm{~nm}$ ) of the supernatants were recorded with a Shimadzu UV-visible spectrophotometer, then recorded again following acidification with $\mathrm{HCl}$ (final pH 2 to 3). Chl a and phaeopigment concentrations were calculated per gram of wet sediment with standard spectrophotometric equations for microalgae (Lorenzen 1967). The efficiency of the first extraction was determined from the total pigment accumulated after 3 separate, serial extractions of the same sample. Concentration estimates for the remaining samples were adjusted based on 1 extraction using the average extraction efficiency for these sediments $(40 \%, \mathrm{n}=18)$. Carbon biomass of benthic microalgae (BMA) was estimated using a ratio of $40 \mu \mathrm{g} \mathrm{C}: \mu \mathrm{g} \mathrm{chl} a$, which is at the low end of the range of previous estimates for estuarine BMA (De Jonge \& Colijn 1994).

Bacteria. Bacteria with intact cytosolic esterases were enumerated in replicate sediment samples $(1 \mathrm{~g})$ dispersed in $2 \mathrm{ml}$ of FSW, then stained with $50 \mu \mathrm{l}$ of $0.5 \mathrm{mM}$ of CellTracker green (CTG, chloromethylfluorescein diacetate, Invitrogen). CTG is a non-fluores- 
cent substance that freely diffuses into cells and becomes fluorescent and impermeant upon hydrolysis by cytosolic enzymes. Metabolically activated dyes have the advantages of high specificity for living cells and reduced non-specific labeling (Epstein \& Rossel 1995). Dispersing the bacteria into a slurry oxygenates sediments and may stimulate bacterial activity. Therefore, the portion of bacteria that are CTG positive are defined here as 'potentially active bacteria'. Cells were fixed after a $2 \mathrm{~h}$ incubation by adding $1 \mathrm{ml}$ of $16 \%$ glutaraldehyde, then refrigerated $(4 \pm$ $2{ }^{\circ} \mathrm{C}$ ) in the dark until analysis. These sediment samples were also used for counts of protists, meiofauna, and total bacteria.

A subsample of this slurry $(1 \mathrm{~g})$ was dispersed in $1 \mathrm{ml}$ of $0.04 \mathrm{M}$ tetrasodium pyrophosphate and placed in a low energy sonic bath for $20 \mathrm{~min}$. This suspension was vortexed, then serially diluted 1:10 in the tetrasodium pyrophosphate solution 3 times with sonication at each dilution (1:1000 final dilution) to separate bacteria from particles and to disperse colonies (Weinbauer et al. 1998). One milliliter of the dilution was then filtered onto $0.2 \mu \mathrm{m}$ Anodisc filters (Whatman). For these and all other slide preparations, $40 \mu \mathrm{l}$ of 5:1 Citifluor:Vectashield was used as a mounting medium to reduce fluorochrome photobleaching. Potentially active bacteria were counted on a Leica DMX RA epifluorescence microscope using blue excitation (450 to $490 \mathrm{~nm}$, dichromatic mirror $510 \mathrm{~nm}$, longpass filter $515 \mathrm{~nm}$ ) at 400- and 1000-fold magnification. All bacteria in the sample ('total bacteria') were enumerated, as described above, after staining the bacterial suspension with SYBR Green II (SYBR). At least 10 fields were counted per filter, usually resulting in >>300 cells sample $^{-1}$. Raw data were adjusted for dilutions and fixative additions. The final adjusted concentrations are reported as cells $\mathrm{g}^{-1}$ wet sediment.

The size distribution of bacterial cells was determined by analyzing images of 12 to 15 fields for each replicate subsample, captured at 1000 -fold magnification with a Hamamatsu CCD digital camera. Cells were automatically sized with image analysis software (Image Pro Plus 4.1). A stage micrometer was used to calibrate the image analysis program, and calibration was verified with 0.66 and $1.0 \mu \mathrm{m}$ diameter fluorescent spheres. After manually excluding dividing cells, colonies, and non-bacterial objects from the images, the average length and width of all remaining cells in images from each time point and replicate was determined. Bacterial biovolume $\left(V, \mu \mathrm{m}^{3}\right)$ was calculated as:

$$
V=\frac{\pi}{4} W^{2}\left(L-\frac{W}{3}\right)
$$

where $L$ and $W$ are the average cell length and width (in $\mu \mathrm{m}$ ), respectively (Bratbak 1985). Cell volumes were converted into biomass $(M$, pg $C)$ by the following allometric relationship (Norland 1993):

$$
M=0.09 V^{0.9}
$$

Total and potentially active bacterial community biomass was the product of cell concentration and mean biomass of the bacterial cells at each time point (average $n=607$; range: 369 to 825 ). The frequency of dividing cells (FDC) was determined by counting the number of dividing cells with a clear septum per 300 SYBR-stained cells (Hagström et al. 1979).

Protists and meiofauna. Benthic protists and meiofauna were extracted from preserved sediments using a density gradient created with a colloidal silica solution following published methods (Epstein 1995). Briefly, $6 \mathrm{ml}$ of Percoll (density $1.13 \mathrm{~g} \mathrm{ml}^{-1}$; Amersham Biosciences) was placed in $10 \mathrm{ml}$ tubes and centrifuged in a fixed angle rotor $(30 \mathrm{~min}$ at $30000 \times g)$ to create a density gradient. Wet sediment slurry $(\sim 2 \mathrm{~g})$ was added to the top of the gradient, then the tubes were centrifuged in a swinging bucket rotor $(60 \mathrm{~min}$ at $2000 \times g)$. The supernatant was removed and placed in a clean $15 \mathrm{ml}$ centrifuge tube. The remaining sediment was resuspended in $1 \mathrm{ml}$ of Percoll, centrifuged in the swinging bucket rotor again, and the supernatant was combined with the initial supernatant. A dual stain of 4',6-diamidino-2-phenylindole (DAPI) and fluorescein isothiocyanate (FITC) was added to the combined supernatant, and the sample was incubated at $4 \pm 2{ }^{\circ} \mathrm{C}$ for a minimum of $60 \mathrm{~min}$. The dual stain was useful in identifying cells, as FITC labels cell proteins and DAPI labels nuclei (Sherr \& Sherr 1993). The supernatant was centrifuged again to settle any sand grains remaining in suspension. The extraction efficiency of this method was determined by counting the total number of organisms extracted from a sample by 3 additional serial extractions $(n=6)$. On average $>90 \%$ of the total biomass was obtained in the first extraction, so counts from the first extraction were used without correction.

The extract was filtered through a $5 \mu \mathrm{m}$ pore size, black polycarbonate filter (Osmonics), and the organisms retained were counted using standard blue excitation for FITC and UV excitation filter sets (UV: 340 to $380 \mathrm{~nm}$, dichromatic mirror $400 \mathrm{~nm}$, longpass filter $425 \mathrm{~nm}$ ) for DAPI. Because the biomass of autotrophic protists is included in the chl a-based estimates of BMA biomass, only heterotrophic protists (cells lacking chloroplasts visible under green excitation; 515 to $560 \mathrm{~nm}$, dichromatic mirror $580 \mathrm{~nm}$, longpass filter 590) were enumerated. Large protists and meiofauna (mostly nematodes) were counted at 100 -fold magnification by scanning the entire filter. Flagellates lacking chloroplasts were counted at 400-fold magnification along transects through the filter. Large $(>20 \mu \mathrm{m}$ in 
equivalent spherical diameter, ESD) heterotrophic protists (mainly ciliates and testate amoebae) were grouped into 15 common morphotypes, and the average size of each morphytope was determined from the length and width of $>30$ individuals using image analysis software (ImagePro Plus 4.1). Common ciliates were identified when possible using taxonomic guides (Carey 1992). Flagellates were grouped into 3 size ranges, and the average dimensions for each size range were based on $>30$ individuals. Nematodes were grouped into 4 size categories with the average dimensions based upon 60 individuals. Individual dimensions were used to calculate biovolume and biomass of protists (Putt \& Stoecker 1989, Wetzel \& Likens 1991) and nematodes (Baguley et al. 2004).

Bacterial grazing experiments. Grazing by sediment protists on bacteria was measured by the fluorescently stained sediment (FSS) method (Starink et al. 1994). In this method, sediment bacteria are labeled by adding a fluorescent stain directly to the sediment. Excess stain is removed by repeated rinsing. Sediment containing stained cells is mixed with an unstained sample of sediment, and the quantity of stained bacterial cells ingested is determined by enumerating cells in protist food vacuoles. Grazing rate is calculated from ingestion and the ratio of FSS bacteria to total bacteria. The advantage of this method is that FSS contains a natural assemblage of living bacterial prey (including both free-living and particle-associated bacteria). Therefore, potential artifacts arising from selective grazing (e.g. preferences for cell size, motility, etc.) are reduced. To avoid non-specific labeling, CTG was used as the label, and the ratio of labeled cells to total cells in FSS was determined as described above.

To produce FSS, sediments were collected from the study site $1 \mathrm{~d}$ prior to the start of the observation period. Approximately $20 \mathrm{~g}$ of sediment from the top $1 \mathrm{~cm}$ of a grab sample was placed in a $50 \mathrm{ml}$ conical centrifuge tube. The sediment was dispersed with $1 \mathrm{ml}$ of FSW, then $50 \mu \mathrm{l}$ of $0.5 \mathrm{mM}$ CTG was added to the slurry. The sample was incubated in creek water for $>10 \mathrm{~h}$, then the slurry was centrifuged $(20 \mathrm{~min}$ at $2000 \times g$ ). The supernatant was discarded and the FSS dispersed in $\sim 20 \mathrm{ml}$ of FSW and centrifuged again. This process was repeated for a total of $3 \mathrm{FSW}$ washes. Washed FSS was incubated in creek water prior to use. For each replicate sample, $10 \mathrm{~g}$ of sediment was added to a $50 \mathrm{ml}$ centrifuge tube and dispersed in $5 \mathrm{ml}$ of FSW. Roughly $2.5 \mathrm{~g}$ of FSS was weighed on the tube cap. The experiment was started by placing the cap on the centrifuge tube and thoroughly mixing the sediment by inverting the tube. A control consisting of non-stained sediment was run at each time point to determine if naturally fluorescent materials occur in food vacuoles or if artifacts of fixation can mimic prey ingestion. Samples were incubated at the ambient creek water temperature for $15 \mathrm{~min}$, as digestion can reduce the apparent number of ingested cells if incubation times are $>15$ min (Sherr et al. 1988). Incubations were stopped by adding $1 \mathrm{ml}$ of $16 \%$ glutaraldehyde, then samples were stored in the dark and refrigerated $\left(4 \pm 2^{\circ} \mathrm{C}\right)$ until analysis.

The rate of bacterivory was determined by enumerating bacteria in the food vacuoles of at least 30 protists per replicate sample (except at 11:00 h, when 1 replicate was lost). Protists were extracted from sediments and collected on filters as described above. Protists were located by transmitted light microscopy (100-fold magnification) as the $5 \mu \mathrm{m}$ pore size filters were relatively translucent. Fluorescent, bacteria-sized particles inside protists were counted by epifluorescence microscopy under blue excitation as described above for CTG-stained, potentially active bacteria. Grazing was determined as both the average number of bacteria per protist examined (per capita grazing) and as the overall potential grazing impact determined by the average number of bacterial cells per unit of protist biovolume, multiplied by the total biovolume of protists (including flagellates, ciliates, and amoeba) at each time point. Because there was no relationship between cell size and ingestion (data not shown), this method allows for the extrapolation of the per capita grazing rate to the entire size range of protists. Fluorescent food vacuoles with an indistinct number of labeled bacteria were scored conservatively as containing 1 bacterium.

Food web model. The interactions between bacteria $(B)$ and bacterivorous protists $(P)$ were modeled with the Lotka-Volterra equations:

$$
\begin{aligned}
& \frac{\mathrm{d} B}{\mathrm{~d} t}=\mu B-F P(B-T) \\
& \frac{\mathrm{d} P}{\mathrm{~d} t}=e F P(B-T)-\mathrm{d} P
\end{aligned}
$$

The variables are described in Table 1. The initial biomass values for total bacteria, bacterivorous protists, and meiofauna were the average of all 8 observations, set to: $51,2.8$, and $2.4 \mu \mathrm{g} \mathrm{C} \mathrm{gws}^{-1}$, respectively. We performed 3 simulations to investigate the roles of feeding thresholds $(T)$ and predation pressure on bacterivorous protists. In these simulations, protist mortality is attributed to meiofauna $(d=$ $M \times F_{\mathrm{M}}$, see Table 1); meiofauna concentration was assumed to remain constant over the simulation time span. Each simulation was performed 1000 times with parameter values randomly chosen from a normal distribution within $10 \%$ of the mean value. For all of these simulations, mean protist clearance rate was set to the mean of all 8 field observations 
Table 1. Variables and units in the food web model. Values used in the simulations are reported in the text. gws: grams of wet sediment

\begin{tabular}{|c|c|c|}
\hline Variable & Description & Units \\
\hline \multicolumn{3}{|l|}{ Biomass } \\
\hline$B$ & Bacteria & $\mu \mathrm{g} \mathrm{C} \mathrm{gws}{ }^{-1}$ \\
\hline$P$ & Bacterivorous protists & $\mu g \mathrm{Cgws}^{-1}$ \\
\hline$M$ & Meiofauna & $\mu \mathrm{g} \mathrm{C} \mathrm{gws}{ }^{-1}$ \\
\hline \multicolumn{3}{|l|}{ Parameters } \\
\hline$\mu$ & Bacterial growth rate & $\mathrm{d}^{-1}$ \\
\hline$F$ & Protist clearance rate & gws $\mu \mathrm{g} \mathrm{C}^{-1} \mathrm{~d}^{-1}$ \\
\hline & Meiofauna clearance rate & gws $\mu \mathrm{g} \mathrm{C}^{-1} \mathrm{~d}^{-1}$ \\
\hline$d=M \times F_{\mathrm{M}}$ & Protist mortality rate & $\mathrm{d}^{-1}$ \\
\hline$e$ & Protist growth efficiency & $\mu g \mathrm{C} \mu \mathrm{g} \mathrm{C}^{-1}$ \\
\hline
\end{tabular}

(0.037 gws $\left.\mu \mathrm{g} \mathrm{C}^{-1} \mathrm{~d}^{-1}\right)$, growth efficiency was 0.3 , and initial biomass values were as specified above. The mean and standard deviations of bacterial and protist biomass were generated from 1000 model runs, with a total incubation time of $5 \mathrm{~d}$ sampled at $0.2 \mathrm{~d}$ intervals. We assumed that the system was closed (i.e. no imports or exports from the system), and that bacterial growth rate was exponential. In Simulation I, the threshold bacterial biomass ( $T$ ) was set to 10 or $20 \mu \mathrm{g}$ $\mathrm{C} \mathrm{gws}^{-1}$. Bacterial biomass available for protist ingestion was equal to the biomass minus $T$, and no bacterivory occurred when the bacterial biomass was less than $T$. In Simulation II, $T$ was set to zero, and the clearance rate of meiofauna-ingesting protists was set to either 0.05 or 0.1 gws $\mu \mathrm{g} \mathrm{C} \mathrm{d}^{-1}$. Finally, in Simulation III, both predation and threshold feeding occurred in concert with runs initialized using the mean values listed above.

\section{RESULTS}

\section{Biomass}

The physical conditions during sampling, including temperature, salinity, photosynthetically active radiation (PAR), and granulometry will be reported elsewhere (authors' unpubl. data). There was no significant difference between porosity of cores taken during tidal emersion and immersion ( $t$-test, $\mathrm{df}=4, \mathrm{p}>0.05$ ); therefore, we assume that compaction of these sediments during emersion does not lead to significant changes in biomass density over a tidal cycle (sensu Perkins et al. 2003). Chl a ranged from $8.9 \pm 0.9$ to $12 \pm$ $1.0 \mu \mathrm{gws}^{-1}( \pm \mathrm{SD})$ in the top $1 \mathrm{~cm}$, corresponding to BMA biomass of 0.36 to $0.48 \mathrm{mg} \mathrm{gws}^{-1}$ (Fig. 1). Phaeopigment concentrations were $<14 \%$ of chl a concentrations and were not significantly different from zero in several samples.

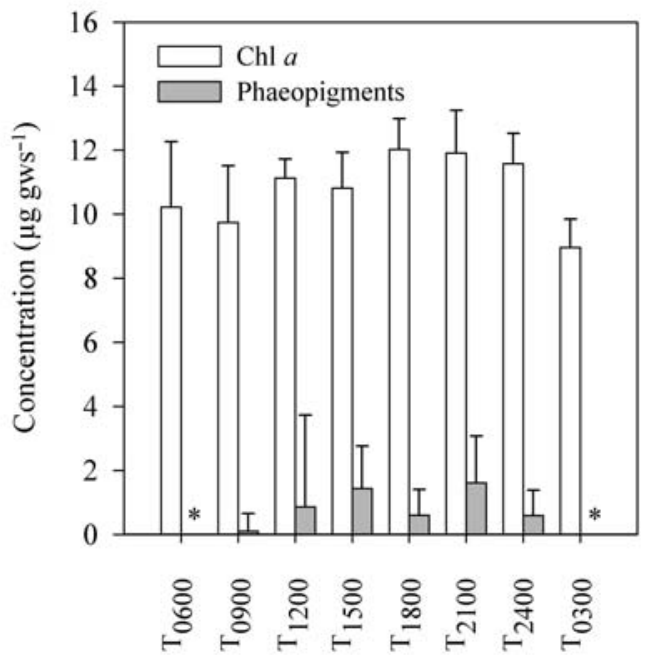

Fig. 1. Chlorophyll a (chl a) and phaeopigment concentrations $\left(\mu \mathrm{g} \mathrm{gws}{ }^{-1}\right)$ over the study period. Error bars show the standard deviation of the mean $(n=3)$. Negative values are set to zero and denoted by an asterisk

Total bacterial concentrations ranged from $1.4 \times 10^{9}$ to $3.6 \times 10^{9}$ cells gws $^{-1}$; bacterial biomass ranged from

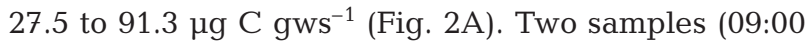
and 21:00 h) contained anomalously high bacterial biomass; in one of these samples (21:00 h), the abundance and biomass were greater than twice the mean of the other time points. Potentially active bacteria were roughly $10 \%$ of total bacteria $\left(0.2 \times 10^{9}\right.$ to $0.4 \times 10^{9}$ cells $\mathrm{gws}^{-1}, 4.9$ to $15.7 \mu \mathrm{g} \mathrm{C} \mathrm{gws}^{-1}$ ) and contributed the most to total bacterial biomass in the 8:00 and 11:00 h samples. The mean bacterial cellular biovolume varied from 0.20 to $0.37 \mu^{3}$, with the largest cells observed at 11:00 h (Fig. 2B), followed by a reduction in mean cell volume corresponding to an increase in the FDC (Fig. 2C).

Ciliates were the major group of large (>20 $\mu \mathrm{m}$ ESD) heterotrophic protists found in our samples, with Uronema marinum and Geleia sp. accounting for a large portion of total abundance and biomass, respectively. Testate amoeba were also common among large protists $\left(19 \pm 10\right.$ cells gws $^{-1}$, mean \pm SD). Total abundance of large protists ranged from 67 to 245 cells $\mathrm{gws}^{-1}$ (Fig. 3A), corresponding to 1.3 to $3.4 \mu \mathrm{g} \mathrm{C} \mathrm{gws}^{-1}$. Small protists $(<20 \mu \mathrm{m}$ ESD), mostly flagellates, were always abundant (Fig. 3B). Despite high concentrations ranging from 2200 to 4900 individuals $\mathrm{gws}^{-1}$, the biomass of small protists ( 0.33 to $0.73 \mu \mathrm{g} \mathrm{C} \mathrm{gws}^{-1}$ ) was a minor component of total microbenthic biomass. Nematodes were the dominant metazoan group found at the study location and, along with a few harpacticoid copepods, comprised almost the entire meiofaunal biomass. The concentration and biomass of meiofauna ranged from 17 to 65 individuals $\mathrm{gws}^{-1}$ (Fig. 3C), corresponding to a biomass contribution of 1.2 to $4.5 \mu \mathrm{g} \mathrm{C} \mathrm{gws}^{-1}$. 

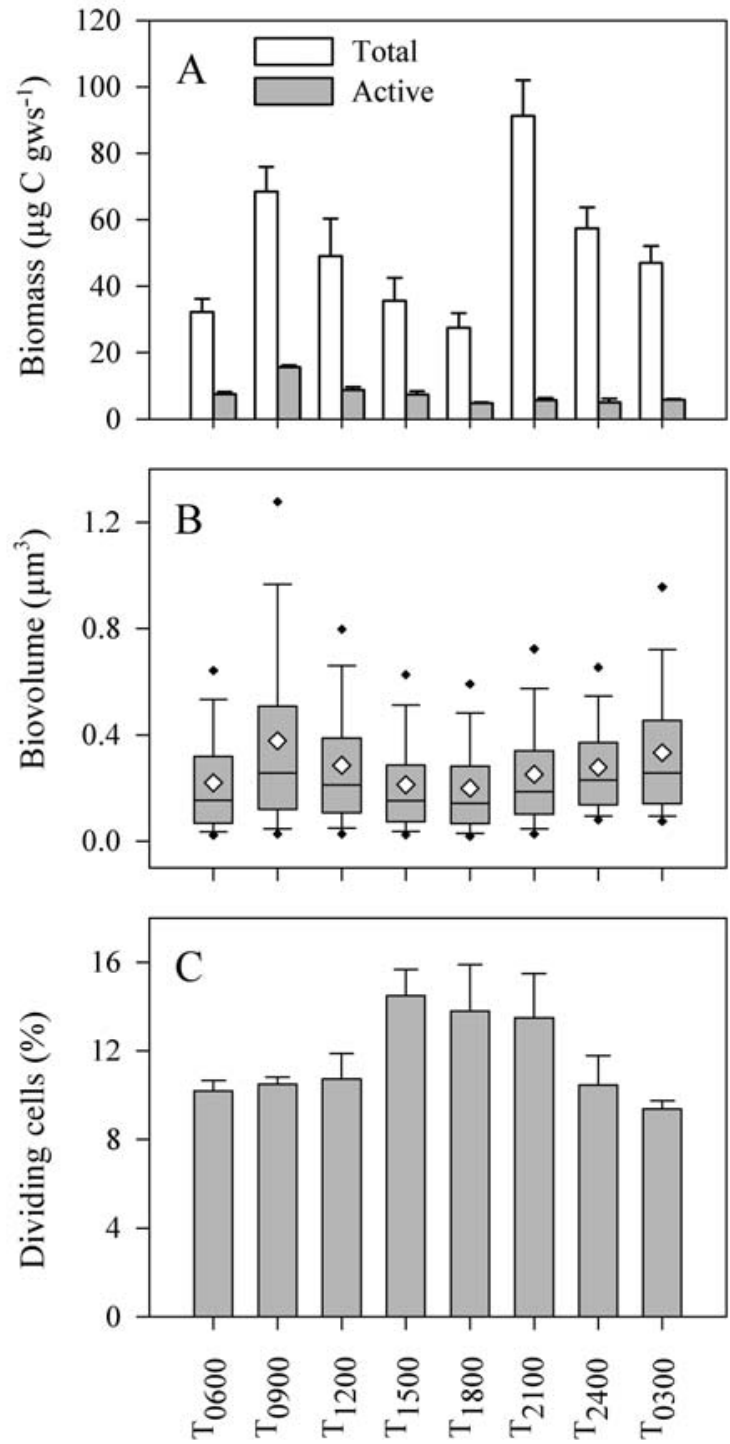

Fig. 2. (A) Mean concentration of total and potentially active ('active') bacteria in the top $1 \mathrm{~cm}$ of sediment. (B) Biovolume distributions of total bacteria; dots and error bars represent the upper and lower 5th and 10th percentile, respectively; the box indicates 25,50 , and $75 \%$ of the data; mean values are indicated with a white diamond, $\mathrm{n}=369$ to 825. (C) Mean frequency of dividing cells. (A) and (C): Error bars show the standard deviation of the mean $(n=3)$

Overall, the combined microbenthic biomass (including bacteria) ranged from 0.4 to $0.6 \mathrm{mg} \mathrm{C} \mathrm{gws}^{-1}$ (Fig. 4). This accounts for 2 to $3 \%$ of total organic matter in the sediment. BMA was $>80 \%$ of the total microbenthic biomass, while bacteria ranged from 5 to $16 \%$ of the total biomass. The contributions of heterotrophic protists and meiofauna ranged from 0.3 to $0.8 \%$ (mean: $0.6 \%$ ) and 0.2 to $0.8 \%$ (mean: $0.5 \%$ ) of total microbenthic biomass, respectively. The ratio of protist to bacterial biomass ranged from 0.03 to 0.12 for
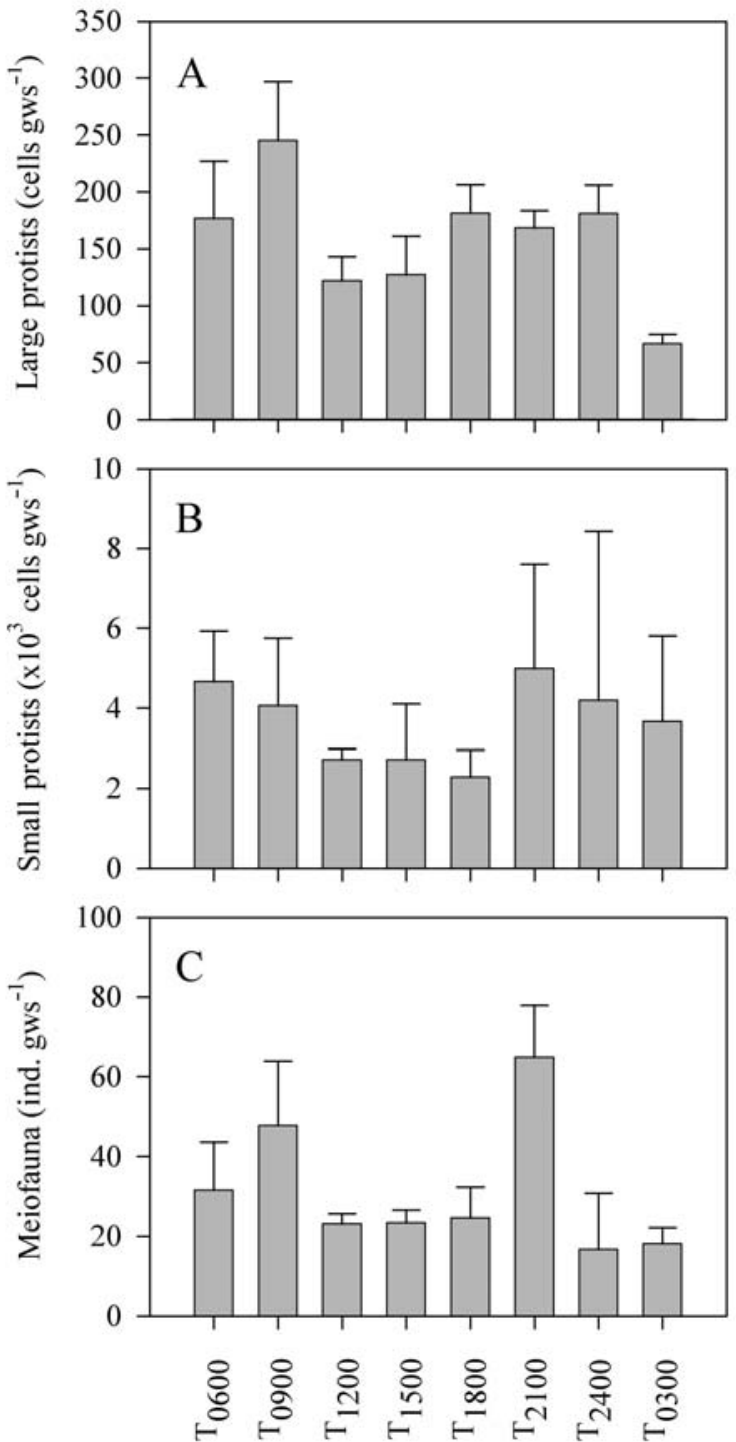

Fig. 3. Total concentration of (A) large heterotrophic protists ( $>20 \mu \mathrm{m}$ ESD), (B) small heterotrophic protists $(<20 \mu \mathrm{m}$ ESD), and $(C)$ meiofauna in the top $1 \mathrm{~cm}$ of sediment throughout the study period. Error bars show the standard deviation of the mean $(n=3)$

large protists; for small protists, the protist to bacteria biomass ratio was always $<0.02$ (Fig. 5A), and the meiofauna to bacteria biomass ratio was between 0.02 and 0.08$)$. However, the ratio of meiofauna to total protists was often $>1$ and, in 1 case $\left(\mathrm{T}_{2100}\right)$, was equal to 1.9 (Fig. 5B).

\section{Bacterial grazing}

Both the individual (mean per capita grazing rate) and the total protist community grazing rate (hereafter 'grazing impact') were highest in the morning samples (09:00 

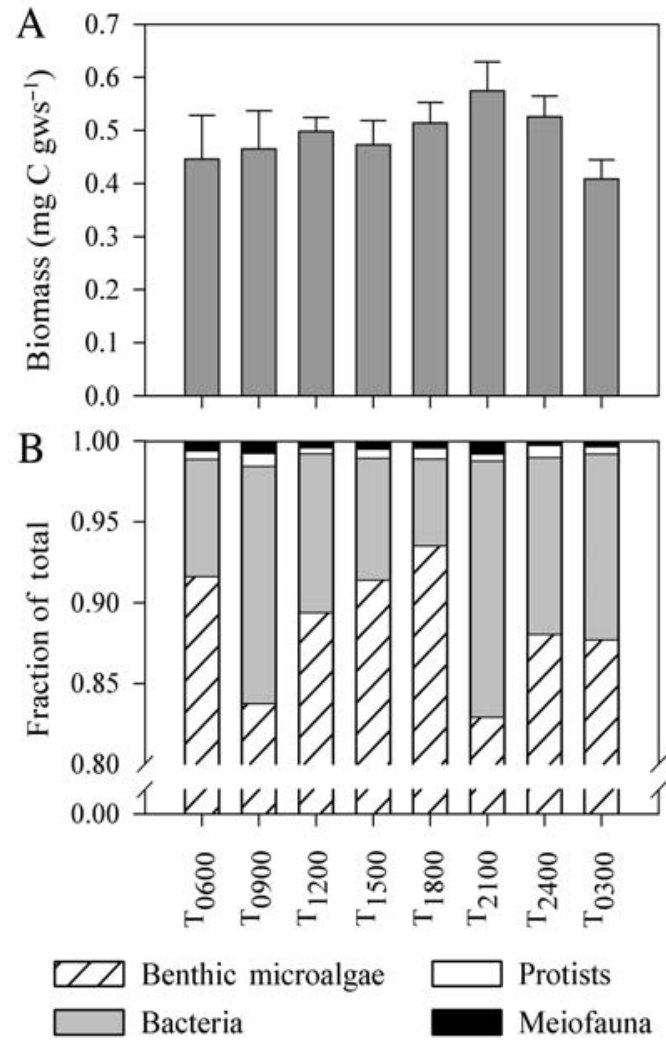

Fig. 4. (A) Total benthic biomass at all sample times. Error bars show the standard error of the mean $(n=3)$. (B) Relative distribution of biomass between themajor groups

and 12:00 hi Fig. 6). However, there were no significant differences between protist grazing impacts measured at different times throughout the day $\left(\right.$ ANOVA, $F_{7,15}=$ $1.78, \mathrm{p}>0.05)$. The per capita grazing rate declined steadily to a minimum at 21:00 $\mathrm{h}$. In all cases, only a small fraction of the available bacterial biomass was lost to protist grazing: 0.1 to $1.1 \% \mathrm{~h}^{-1}$ (mean $0.4 \% \mathrm{~h}^{-1}$ ) of the total standing stock of bacteria or 0.6 to $4.7 \% \mathrm{~h}^{-1}$ of the potentially active bacteria (mean $2.4 \% \mathrm{~h}^{-1}$ ). Grazing impact did not co-vary significantly with total or potentially active bacterial concentration (linear regressions, $\mathrm{df}=7, \mathrm{R}^{2}<0.44, \mathrm{p}>0.05$ in both cases). The turnover time (total bacterial concentration/grazing impact) ranged from 3.8 to $75 \mathrm{~d}$ in these samples.

\section{Food web model}

Simulation I demonstrated that setting a threshold bacterial concentration $(T)$ limited the final protist to bacteria ratio to $<0.65$ and $<0.35$ when $T$ was set to 10 and $20 \mu \mathrm{g} \mathrm{C} \mathrm{gws}^{-1}$, respectively (Fig. 7). Similarly, the protist to bacteria ratio was $<0.66$ and $<0.32$ when the clearance rate of meiofauna was set to 0.05 and 0.10 gws $\mathrm{gg}^{-1} \mathrm{C} \mathrm{d}^{-1}$, respectively. With both threshold

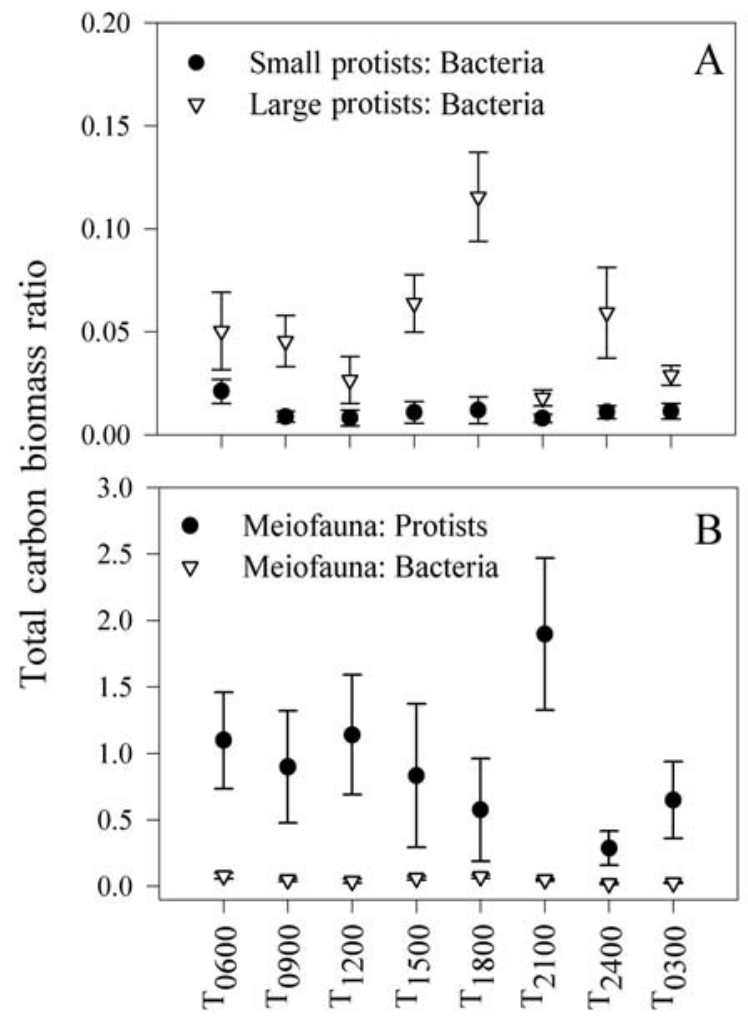

Fig. 5. Biomass ratios of (A) small and large protists to total bacteria and (B) meiofauna to protists and bacteria. Error bars show the standard deviation of the mean $(n=3)$

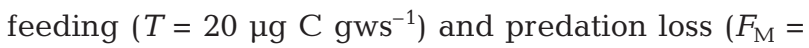
$0.10 \mathrm{gws} \mathrm{g} \mathrm{g}^{-1} \mathrm{C} \mathrm{d}^{-1}$ ), the final protist to bacteria ratio ranged from the initial value of 0.05 to 0.10 over the $5 \mathrm{~d}$ time span (Fig. 7).

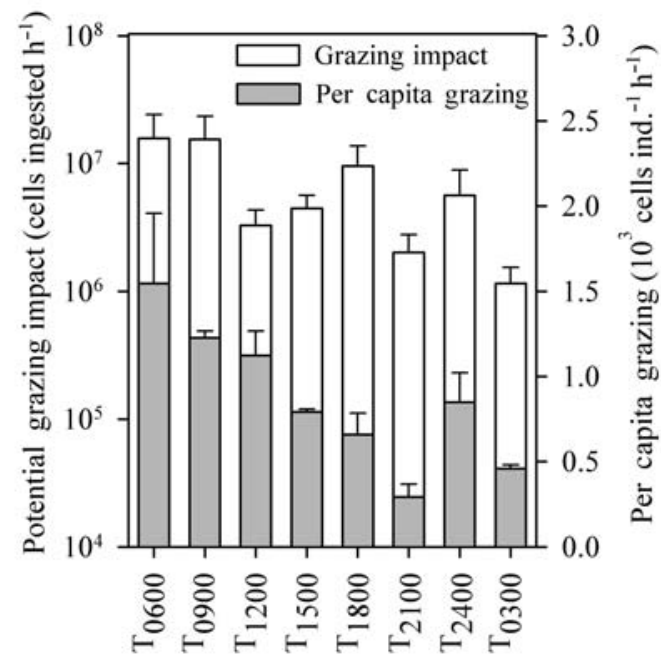

Fig. 6. Mean per capita bacterial uptake rates and potential grazing impact on bacteria of the total heterotrophic protist community. Error bars show the standard deviation of the mean $(n=3)$ 


\section{DISCUSSION}

Intertidal sediments are dynamic environments where the benthic microbial community is closely coupled to the pelagic through patterns of settling and resuspension driven by tidal flow (e.g. Shimeta \& Sisson 1999). We hypothesized that the protist grazing impact varies over a diel period, and that high grazing during portions of the day could reduce the standing stock of bacteria. The grazing impact of protists could drive down the standing stock of bacteria in some samples. For example, at $\mathrm{T}_{0600}$ the bacterial growth rate necessary to balance the loss to grazing would be $0.26 \mathrm{~d}^{-1}$. While active subpopulations of sediment bacteria can have growth rates much higher than this value, total bacterial community growth rates in coastal sediments are $<0.1 \mathrm{~d}^{-1}$ (Luna et al. 2002). However, throughout most of the day, the grazing impact would not sufficiently balance even low bacterial growth rates. The per capita ingestion rates of bacteria by protists measured in the present study are at the high end of values reported for benthic (Kemp 1988) and pelagic (Sherr et al. 1988) bacterivorous protists. Therefore, the low abundance of protists (relative to bacteria) is more likely to be the cause of the persistent high bacterial standing stocks in these sediments. Potential factors limiting the accumulation of bacterivorous protist biomass, and, in turn, more complete utilization of benthic bacteria, are considered below.

First, benthic protists may have low growth efficiencies, and the high per capita ingestion rates observed do not translate into high protist production rates. Aerobic protists in oxic environments have high growth efficiencies (e.g. Ohman \& Snyder 1991) and high intrinsic growth rates (Banse 1982). At the mean clearance rates observed, the potential production of these bacterivores should be high, even at low or moderate growth efficiencies. However, the majority of these sediments were anoxic, and the growth efficiencies of anaerobic benthic bacterivores is likely much lower-roughly $25 \%$ that of aerobic metabolism (Fenchel \& Finlay 1990).

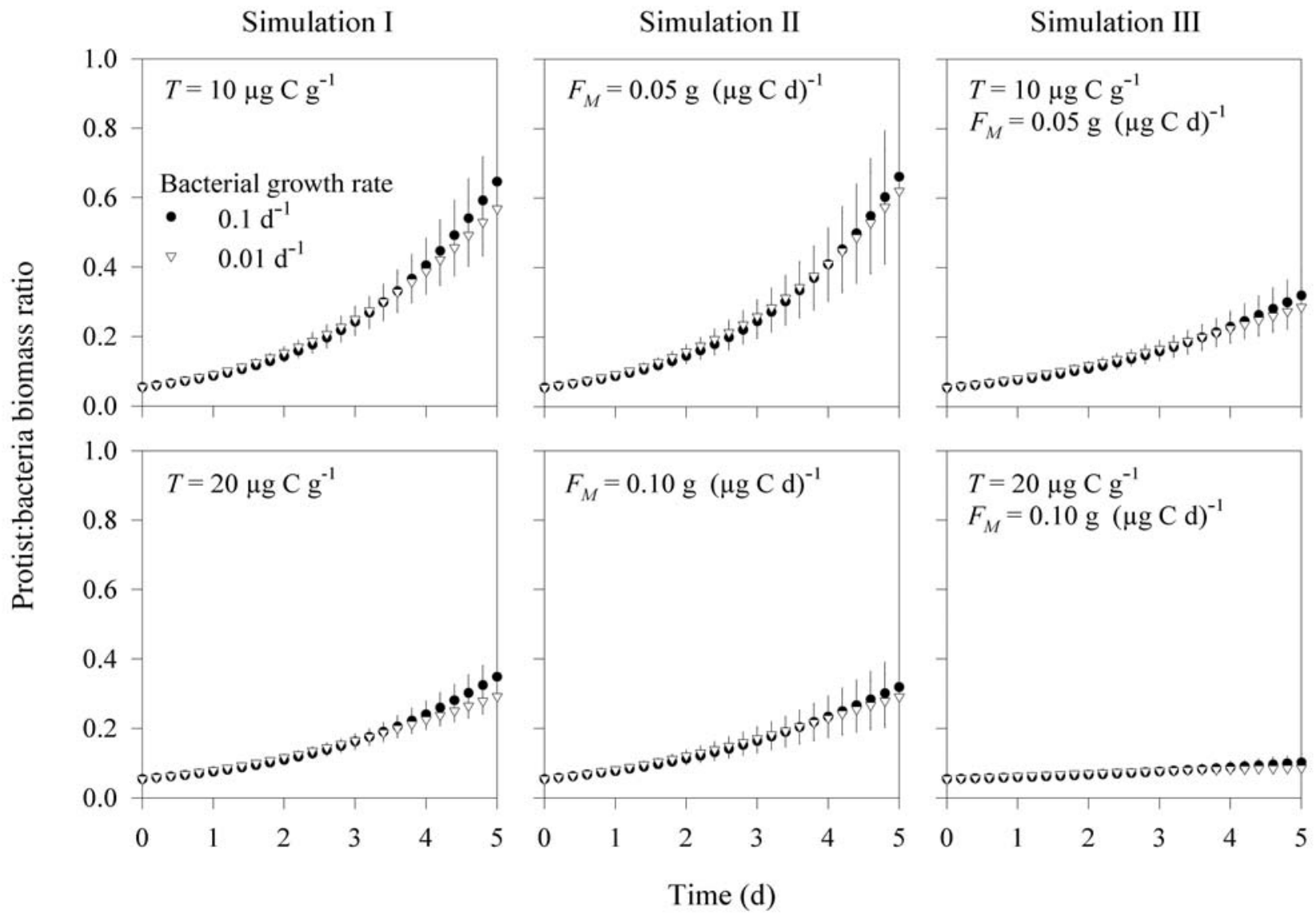

Fig. 7. Results of model simulations I to III, indicating the protist to bacteria biomass ratio over $5 \mathrm{~d}$. The threshold bacterial concentration ( $T$ ) is set to 10 (top panel) and $20 \mu \mathrm{g} \mathrm{C} \mathrm{gws}^{-1}$ (bottom panel) in Simulation I. In Simulation II, the clearance rate of meiofauna consuming protists $\left(F_{\mathrm{M}}\right)$ is set at 0.05 (top panel) and $0.1 \mathrm{gws} \mu \mathrm{g} \mathrm{C} \mathrm{C}^{-1} \mathrm{~d}^{-1}$ (bottom panel). Simulation III combines the smaller (top panel) and larger (bottom panel) $T$ and $F_{\mathrm{M}}$ values. Simulations were conducted using both low $\left(0.01 \mathrm{~d}^{-1}\right)$ and high $\left(0.1 \mathrm{~d}^{-1}\right)$ bacterial growth rates. Error bars indicate the standard deviation of the mean value of 1000 model runs 
Second, a majority of bacteria in sediments may be effectively unavailable for ingestion by protists. The high standing crops of benthic bacteria may result from refuge in microhabitats, which protect bacteria from viral infection and bacterivores. Grain size distributions explain the majority of bacterial biomass variability in intertidal sediments (Dale 1974). Bacterial adhesion to particles provides a refuge from protist grazing, allowing for a higher standing stock of prokaryotic biomass. In laboratory experiments, feeding rates on unattached, interstitial bacteria were double the rates on particle-bound bacteria (Eisenmann et al. 1998). Solitary and unattached bacteria may encounter the heaviest predation pressure from interstitial grazers, which could have consequences for the overall structure of the bacterial community and, in turn, sediment metabolism. For example, bacteria attached to inorganic particles may be protected from grazers, but may also have reduced access to substrate, nutrients, and the electron acceptors necessary for growth (Murray \& Jumars 2002). Conversely, freeliving bacteria have increased access to solutes, but are more likely consumed by bacterivorous protists. The most favorable strategy may vary between these 2 extremes throughout the day. For instance, unattached cells could more readily access labile dissolved organic carbon (DOC) and the oxygen produced when the sediments are illuminated in the late morning. The greatest portion of potentially active bacteria occurred concurrently with the greatest grazing impact at this time, suggesting that unattached cells susceptible to grazing were more abundant than at other times throughout the day. Both occurred during the late morning when the production of labile DOC was likely greatest.

Third, factors such as predation or export into the water column may limit the abundance of protists and, consequently, their grazing impact on the bacteria. The abundance of bacterivorous protists (relative to bacteria) was roughly constant in model simulations when both predation pressure on protists and grazing thresholds were included. If bacterivorous protists are rapidly consumed by meiofauna, the cycling of energy through the microbial loop in sediments could be substantial. Benthic protists may also be advected into the water column due to tidal flow (Shimeta \& Sisson 1999), where they are assimilated into the pelagic food web. For instance, ciliates are efficiently captured and retained by oysters (LeGall et al. 1997). Also, microheterotrophs (including both protists and bacteria) supply a large portion of the carbon and nitrogen necessary for the growth of the ribbed mussel Geukensia demissa (Kreeger \& Newell 2000).

Protist grazing varies throughout the day, and, in some periods, it may be sufficient to reduce bacterial standing stock. The high per capita grazing rates of protists in the morning samples indicates bacterial prey were relatively abundant at these times. In contrast, reduced grazing rates over the day suggest that labile bacteria may become less available for protists. Regardless of these diel variations in per capita grazing, the amount of bacterial carbon consumed does not appear to translate into a high standing stock of bacterivorous protists. The relative biomasses of protists and bacteria may oscillate on time scales greater than those observed in the present study. However, assuming the biomass of these 2 groups remains constant over long periods, the factors limiting the abundance of benthic protists (e.g. low growth efficiencies, predation pressure) will illuminate the causes and consequences of high benthic bacterial biomass.

Acknowledgements. This work was supported by an NSF Georgia Coastal Ecosystems LTER grant (OCE-9982133). M.R.F. was also supported by a UGA Graduate School Assistantship. H. L. Miller III assisted with the design and coding of the food web model. C. Meile critically reviewed an earlier version of this manuscript. We are grateful for the hospitality and logistical support of J. Garbisch and M. Price at the University of Georgia Marine Institute. J. Bernhard, M. Farmer, S. Joye, and C. Meile provided guidance on the design of this project. M. A. Moran and W. Ye kindly provided access to their ultracentrifuge. The comments of 2 anonymous reviewers greatly improved this manuscript. This is Contribution No. 952 of the University of Georgia Marine Science Institute.

\section{LITERATURE CITED}

Baguley JG, Hyde LJ, Montagna PA (2004) A semi-automated digital microphotographic approach to measure meiofaunal biomass. Limnol Oceanogr Methods 2:181-190

Banse K (1982) Cell volumes, maximal growth-rates of unicellular algae and ciliates, and the role of ciliates in the marine pelagial. Limnol Oceanogr 27:1059-1071

Bratbak G (1985) Bacterial biovolume and biomass estimations. Appl Environ Microbiol 49:1488-1493

Carey PG (1992) Marine interstitial ciliates: an illustrated key. Chapman and Hall, Norwell, MA

Dale NG (1974) Bacteria in intertidal sediments: factors related to their distribution. Limnol Oceanogr 19:509-518

De Jonge VN, Colijn F (1994) Dynamics of microphytobenthos biomass in the Ems estuary. Mar Ecol Prog Ser 104:185-196

De Jonge VN, Van Beusekom JEE (1992) Contribution of resuspended microphytobenthos to total phytoplankton in the Ems estuary and its possible role for grazers. Neth J Sea Res 30:91-105

> Eisenmann H, Harms H, Meckenstock R, Meyer EI, Zehnder AJB (1998) Grazing of a Tetrahymena sp. on adhered bacteria in percolated columns monitored by in situ hybridization with fluorescent oligonucleotide probes. Appl Environ Microbiol 64:1264-1269

Epstein SS (1995) Simultaneous enumeration of protozoa and micrometazoa from marine sandy sediments. Aquat Microb Ecol 9:219-227

Epstein SS (1997) Microbial food webs in marine sediments. I. Trophic interactions and grazing rates in two tidal flat communities. Microb Ecol 34:188-198 
Epstein SS, Rossel J (1995) Methodology of in situ grazing experiments: evaluation of a new vital dye for preparation of fluorescently labeled bacteria. Mar Ecol Prog Ser 128:143-150

Fenchel T (1967) The ecology of marine microbenthos. I. The quantitative importance of ciliates as compared with metazoans in various types of sediments. Ophelia 4: 121-137

Fenchel T (1970) Studies on decomposition of organic detritus derived from turtle grass Thalassia testudinum. Limnol Oceanogr 15:14-20

Fenchel T, Finlay BJ (1990) Anaerobic free-living protozoa: growth efficiencies and the structure of anaerobic communities. FEMS Microbiol Ecol 74:269-275

Filippini M, Buesing N, Bettarel Y, Sime-Ngando T, Gessner MO (2006) Infection paradox: high abundance but low impact of freshwater benthic viruses. Appl Environ Microbiol 72:4893-4898

Glud RN, Middelboe M (2004) Virus and bacteria dynamics of a coastal sediment: implication for benthic carbon cycling. Limnol Oceanogr 49:2073-2081

Hagström A, Larsson U, Hörstedt P, Normark S (1979) Frequency of dividing cells, a new approach to the determination of bacterial growth rates in aquatic environments. Appl Environ Microbiol 37:805-812

Hamels I, Muylaert K, Casteleyn G, Vyverman W (2001) Uncoupling of bacterial production and flagellate grazing in aquatic sediments: a case study from an intertidal flat. Aquat Microb Ecol 25:31-42

Kemp PF (1987) Potential impact on bacteria of grazing by a macrofaunal deposit-feeder, and the fate of bacterial production. Mar Ecol Prog Ser 36:151-161

Kemp PF (1988) Bacterivory by benthic ciliates: significance as a carbon source and impact on sediment bacteria. Mar Ecol Prog Ser 49:163-169

Kemp PF (1990) The fate of benthic bacterial production. Rev Aquat Sci 2:109-124

Kreeger DA, Newell RIE (2000) Trophic complexity between producers and invertebrate consumers in salt marshes. In: Weinstein MP, Kreeger DA (eds) Concepts and controversies in tidal marsh ecology. Kluwer, Dordrecht, p 187-220

LeGall S, Hassen MB, LeGall P (1997) Ingestion of a bacterivorous ciliate by the oyster Crassostrea gigas: protozoa as a trophic link between picoplankton and benthic suspension-feeders. Mar Ecol Prog Ser 152:301-306

Lorenzen CJ (1967) Determination of chlorophyll and pheopigments: spectrophotometric equations. Limnol Oceanogr 12:343-346

Luna GM, Manini E, Danovaro R (2002) Large fraction of dead and inactive bacteria in coastal marine sediments: comparison of protocols for determination and ecological significance. Appl Environ Microbiol 68:3509-3513

Murray JLS, Jumars PA (2002) Clonal fitness of attached

Editorial responsibility: Barry \& Evelyn Sherr,

Corvallis, Oregon, USA bacteria predicted by analog modeling. BioScience 52 : 343-355

Norland S (1993) The relationship between biomass and volume of bacteria. In: Kemp PF (ed) Handbook of methods in aquatic microbial ecology. Lewis Publishers, Boca Raton, FL, p 303-308

Ohman MD, Snyder RA (1991) Growth-kinetics of the omnivorous oligotrich ciliate Strombidium sp. Limnol Oceanogr 36:922-935

Perkins RG, Honeywill C, Consalvey M, Austin HA, Tolhurst TJ, Paterson DM (2003) Changes in microphytobenthic chlorophyll $a$ and EPS resulting from sediment compaction due to de-watering: opposing patterns in concentration and content. Cont Shelf Res 23:575-586

Putt M, Stoecker DK (1989) An experimentally determined carbon-volume ratio for marine oligotrichous ciliates from estuarine and coastal waters. Limnol Oceanogr 34: $1097-1103$

Schmidt JL, Deming JW, Jumars PA, Keil RG (1998) Constancy of bacterial abundance in surficial marine sediments. Limnol Oceanogr 43:976-982

Sherr EB, Sherr BF (1993) Staining of heterotrophic protists for visualization by epifluorescence microscopy. Lewis Publishers, Boca Raton, FL

Sherr BF, Sherr EB, Rassoulzadegan F (1988) Rates of digestion of bacteria by marine phagotrophic protozoa: temperature dependence. Appl Environ Microbiol 54:1091-1095

Shimeta J, Sisson JD (1999) Taxon-specific tidal resuspension of protists into the subtidal benthic boundary layer of a coastal embayment. Mar Ecol Prog Ser 177:51-62

Starink M, Krylova IN, Bär-Gilissen MJ, Bak RPM, Cappenberg TE (1994) Rates of benthic protozoan grazing on free and attached sediment bacteria measured with fluorescently stained sediment. Appl Environ Microbiol 60: $2259-2264$

Thoresen M (2004) Temporal and spatial variation in seston available to oysters and the contribution of benthic diatoms to their diet in the Duplin River, Georgia. University of Georgia, Athens

Torsvik V, Sorheim R, Goksoyr J (1996) Total bacterial diversity in soil and sediment communities - a review. J Ind Microbiol 17:170?178

Weinbauer MG, Beckmann C, Hofle MG (1998) Utility of green fluorescent nucleic acid dyes and aluminum oxide membrane filters for rapid epifluorescence enumeration of soil and sediment bacteria. Appl Environ Microbiol 64: 5000-5003

Wetzel RG, Likens GE (1991) Limnological analysis. SpringerVerlag, New York

Wieltschnig C, Fischer UR, Kirschner AKT, Velimirov B (2003) Benthic bacterial production and protozoan predation in a silty freshwater environment. Microb Ecol 46:62-72

Submitted: April 5, 2007; Accepted: January 24, 2008

Proofs received from author(s): May 29, 2008 